\title{
RAの人工関節の術後合併症について
}

\author{
国立福岡中央病院 整形外科 \\ 和田研・近藤 正一 \\ 甲 斐 睦 章・松田秀一 \\ 篠 原 典 夫・横 山庫一郎
}

\section{Postoperative Complications after Total Joint Arthroplasties in Reumatoid Patients}

by

Ken Wada, Masakazu Kondoh, Mutsuaki Kai, Shuichi Matsuda, Norio Shinohara and Koichiroh Yokoyama

Department of Orthopedic Surgery, National Fukuoka Central Hospital

Postoperative complications after 172 Total Knee Arthroplasties (TKA) and 70 Total Hip Arthroplas. ties (THA) for rheumatoid patients were studied. Operations had been performed between 1987 and 1990.

Thirty percent of the TKA and sixty-seven percent of the THR needed postoperative blood transfusions.

Rheumatoid patients have some systemic problems like anemia, gastric ulcers, weakness against bacteria, weak muscles and soft tissues. So, special attention should be paid to the condition of rheumatoid patients before and after total joint arthroplasties.

\section{は じめに}

慢性関節リウマチ（RA）において股関節，膝関節 の人工関節は有力な手術治療の方法となっている. ᄂ かしRAに対する人工関節では，その全身的な特徴と して，貧血の合併，ストレスに対する弱さ，感染に対 する抵抗力の弱さ, 組織の脆弱性や筋力低下など多く の問題点が存在する. 今回，我々はRAの人工関節の 手術合併症を調査し, その問題点について検討した.

\section{対象}

1987. 1. 1 1990. 12. 31 の 4 年間に当院でお こなった慢性関節リウマチに対する人工関節は，膝関 節（TKR）が 120 例 172 関節で，平均年齢 56.6 才, 平均罹病期間 17.8 年であった。使用した機種は, Miller-Galante 82 膝, Miller-Galante II 5 膝, Kinematic Stabilizer 55 膝, Kinemax Stabilizer 29 膝, Kinematic Rotating Hinge 1 膝であった. Miller-Galante および Miller-Galante II のう 48 膝が
セメントレスであり，他の 124 膝はセメントを使用し た。

同じ時期に手術した人工股関節（THR）は 55 例 70 関節で, 平均年齢 56.1 才, 平均罹病期間 15.4 年であっ た。再置換例は除外した。機種は Harris-Galanteを 主として用いており，臼蓋側はセメントレスが 63 股, セメントを使用するタイバックが 7 股であった. ステ ム側はセメントレスが, Harris-Galante 23 股, Anatomic stem 6 股, 合計 29 股, セメント使用の Precoat stem が41 股であった（表 1 ）.

\section{結 果}

a ．セメントレスとセメント使用の比較

TKR 全体の平均出血量は $645 \mathrm{~g}$ であり, 輸血率は 30 \%であった. セメントレスとセメントを比較する と，当然であるが，平均手術時年齢がセメントレスで 若かった. またセメントレスの方が平均手術時間が 16 分短かったが，それに反して平均術後出血がセメ ント使用例より $325 \mathrm{~g}$ 多く, 平均全出血量も $851 \mathrm{~g}$ と 
表 1 当科の RA に対する人工関節

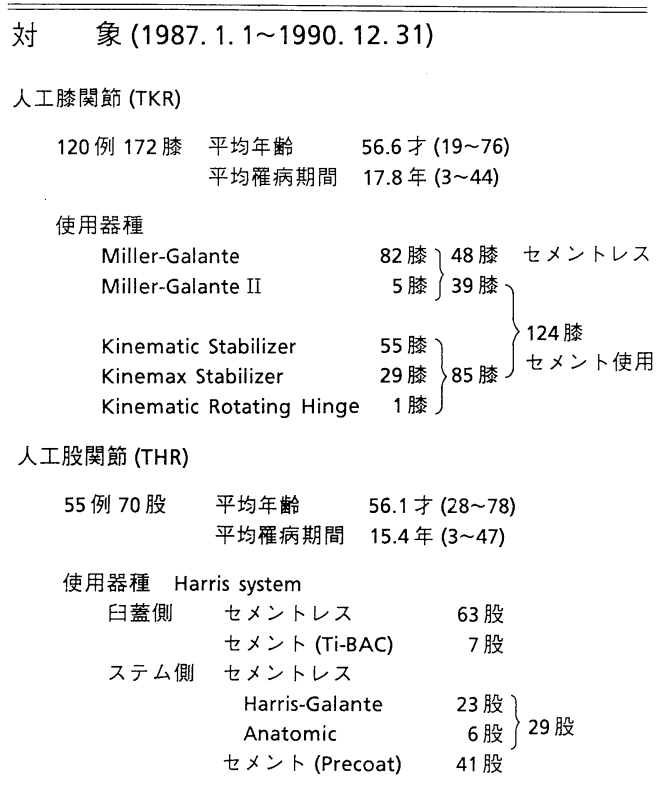

多くなっていた．輸血率も 35 \%と高かった.

THR 全体の平均出血量は $893 \mathrm{~g}$ であり, 輸血率は $67 \%$ と高率であった。ややり平均手術時年齢はセメ ントレスが若かったが,平均手術時間に差はなかった. セメント使用例に大腿骨側のみにセメントをもちいる hybrid 法が多かったためか，セメントレスのほうが 多少出血が多いようであるが大きな差はみられなかっ た. セメントレスで出血量が多いのに輸血率がむしろ 低いのは，年齢が若く，輸血せずに頑張れた症例が含
まれたからと思われた（表 2 ).

b . 術前のへモグロビンの值と輸血率の検討

TKR では，術前のへモグロビン值は， $7.2 \sim 16.2$ $\mathrm{g} / \mathrm{dl}$, 平均 $10.6 \mathrm{~g} / \mathrm{dl}$ であった. へモグロビン值 10 $\mathrm{g} / \mathrm{dl}$ 未満で輸血を必要とした症例は, 64 例中 31 例, $48 \%$ と高率であった. 逆にへモグロビン值 $11 \mathrm{~g} / \mathrm{dl}$ 以 上では輸血を必要とした症例は 59 例中 7 例とわずか であった。

THR では, 術前のへモグロビン值は, $7.4 \sim 19 \mathrm{~g} / \mathrm{dl}$, 平均 $10.5 \mathrm{~g} / \mathrm{dl}$ であった. へモグロビン值 $10 \mathrm{~g} / \mathrm{dl}$ 未 満では輸血を必要とした症例は，30 例中 25 例，83\% と高率であった，逆にへモグロビン值 $12 \mathrm{~g} / \mathrm{dl}$ 以上で は輸血例はなかった（図 1 )。

2 . 全身的合併症

TKR では胃潰瘍 1 例，回腸穿孔 1 例，帯状包疹 3 例がみられた。

THR では胃潰瘍 2 例, 心筋梗塞疑い 1 例, 脳梗塞 疑い 1 例, 肝機能障害 1 例がみられた.

3. 感染

TKR では表層感染が 8 膝に, 遅発性の TKR 感染が 2 例 3 膝にみられた（図 2 )。この 2 例 3 膝は幸いに も持続灌流と抗生物質投与で現在おさまっている. ま た感染疑いが 2 膝にあった。

THR では表層感染の 1 例のみであった.

4. TKR の局所的合併症

創治癒不全 9 膝 (図 3 ), 血腫 9 膝, 皮下出血斑 4 膝, 腓骨神経麻瘏 3 膝, 膝蓋骨骨折, 膝蓋腱断裂, 大腿四 頭筋腱断裂，膝蓋骨脱臼が各 1 膝があった.

表 2 セメントレスとセメント使用の比較

\begin{tabular}{|c|c|c|c|c|}
\hline TKR & 年 齢 & $\begin{array}{ll}\text { 手 } & \text { 術 } \\
\text { 時 } & \text { 間 }\end{array}$ & $\begin{array}{l}\text { 術中出血 }+ \\
\text { 術後出 }=\text { 出血量 }\end{array}$ & 輸血率 \\
\hline セメントレス & $51.2 才$ & 99分 & $23+827=851 \mathrm{~g}$ & $17 / 48=35 \%$ \\
\hline セメント & 58.7才 & 115分 & $63+502=565 \mathrm{~g}$ & $34 / 124=27 \%$ \\
\hline 合 計 & $56.6 才$ & 110 分 & $52+593=645 g$ & $51 / 172=30 \%$ \\
\hline THR & 年 齢 & $\begin{array}{ll}\text { 手 } & \text { 術 } \\
\text { 時 } & \text { 間 }\end{array}$ & $\begin{array}{l}\text { 術中出血 }+ \\
\text { 術後出 }=\text { 出血量 }\end{array}$ & 輸血率 \\
\hline セメントレス & 51.4 才 & 108 分 & $501+479=980 \mathrm{~g}$ & $18 / 29=62 \%$ \\
\hline $\begin{array}{c}\text { セメント } \\
\text { (Hybrid 法を含む) }\end{array}$ & $59.3 才$ & 113分 & $439+396=835 \mathrm{~g}$ & $29 / 41=70 \%$ \\
\hline 計 & $56.1 才$ & 111分 & $464+429=893 \mathrm{~g}$ & $47 / 70=67 \%$ \\
\hline
\end{tabular}



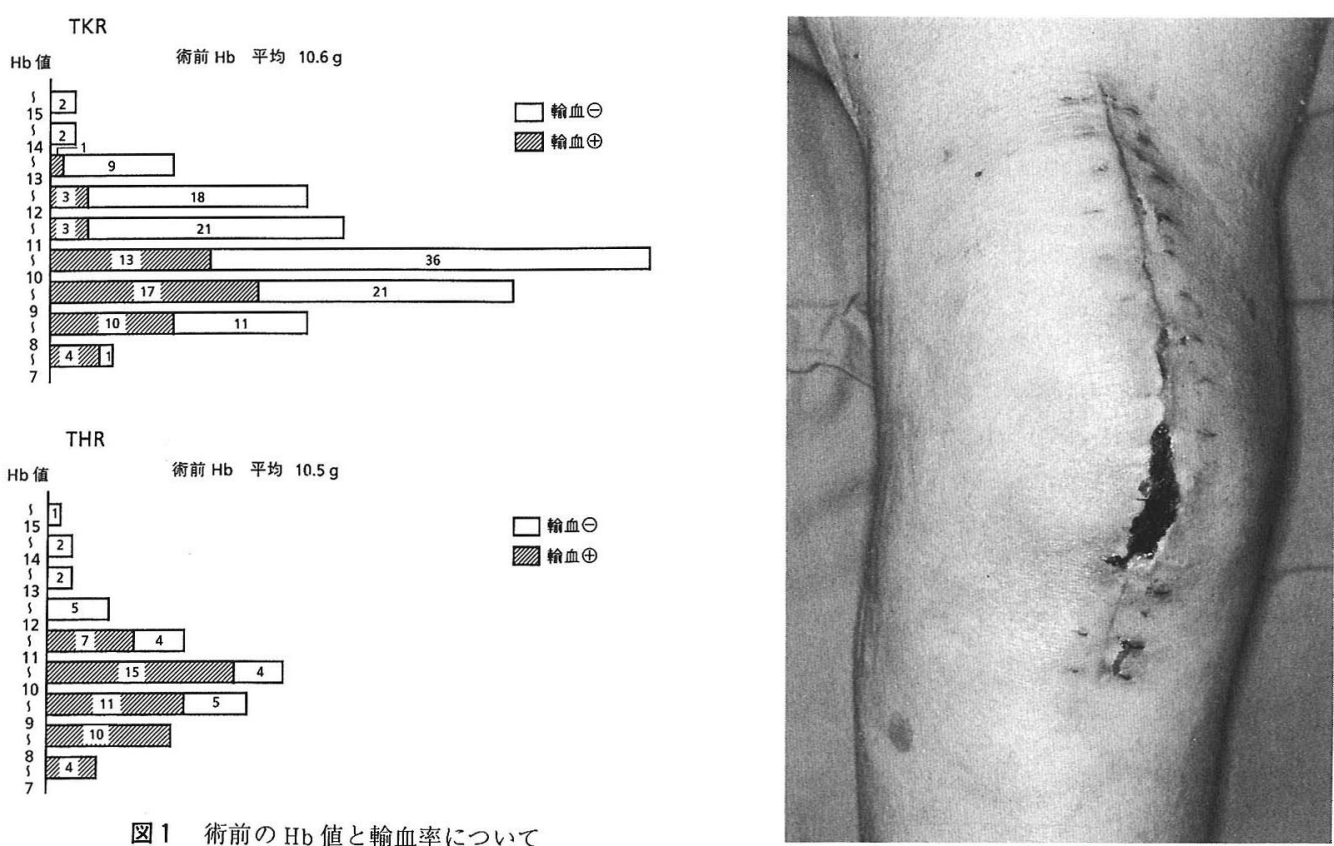

図 $3 T K R$ 後の創治療不全（創縁壊死）

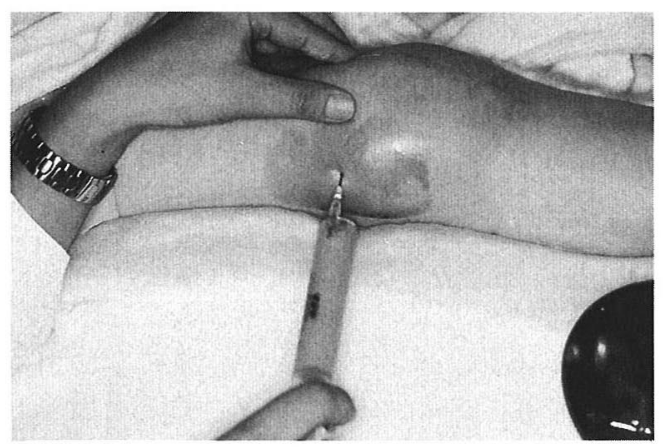

図 2 遅発性 TKR 感染

穿刺により膿を確認しているところ

\section{THR の局所的合併症}

脱且が 7 股（10.0\%）（図 4), 裖創 3 例があった. 脱臼例は全例が 1 力月以内に初回脱臼を起こしてお ク，複数回の脱臼は 2 例にみられた。

\section{考察}

1. 出血について

人工関節置換術の際の出血は，術中の確実な止血に より，ある程度は防ぎ得るものである。しかし，近年 流行してきたセメントレスの人工関節の際には，骨髄 からの出血が止められずに問題となる. Mylod 等 5

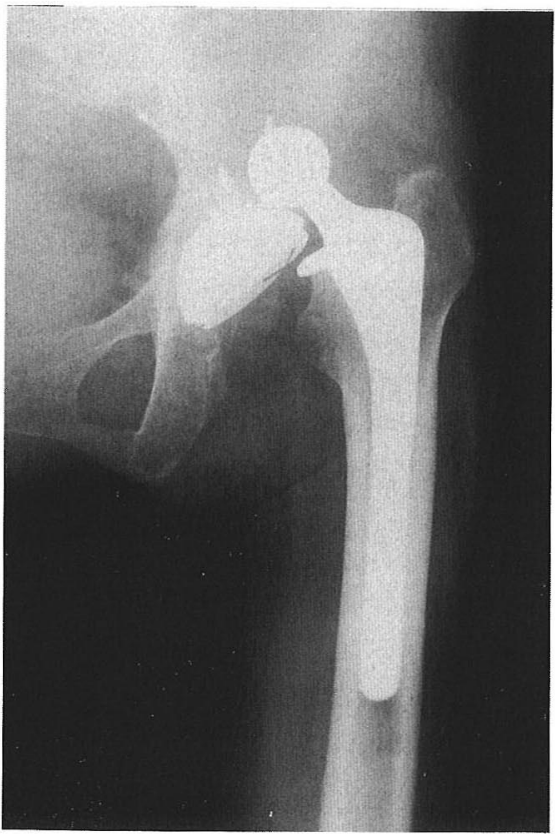

図4 THR 脱臼

も TKRにおいてセメント使用例での平均出血量が $583 \mathrm{~g}$ であったのに対し，セメントレスでは $1478 \mathrm{~g}$ で あったと報告している，今回の調査でも，やはりセx 
ント使用例よりセメントレスのほうが出血量は多かっ た. しかし, 骨萎縮がなく, 変形も少ない若年者にとっ ては，やはりセメントレスの人工関節を選択すべきで あり，それなりの出血を予想した上での対策が必要と なってくる.

またRAでは，ほとんどの症例に貧血が合併してお り，高度の貧血もしばしばみられる。このような際に は輸血が必要となり, 今回の調査でも, TKRで $30 \%$, THR で $67 \%$ と高率に輸血を行なっていた. 特に, 術 前のへモグロビン值が, TKRでは $10 \mathrm{~g}$ 以下，THRで は $12 \mathrm{~g}$ 以下で輸血の確率が高いようであった。

我々は最近，このように術前の貧血が高度な症例に 対して，エリスロポエチンを用いた自己血輸血を行 なっている、へモグロビン值が $10 \mathrm{~g}$ を越えた時点で 採血を行ない, TKR では $800 \mathrm{~g}$, THR では $1200 \mathrm{~g}$ の 貯血を行なって手術に臨んでいる。この自己血輸血に より，同種血輸血の頻度は極端に減少して抢り，貧血 を有する症例の，、工関節置換術に対して有用な方法と 思われた。また，セルセーバーなどの使用も試みてお り，これらを合わせて用いれば同種血輸血はほぼ 100 \%回避できるのではないかと考えている.

2 . 全身的合併症

ストレスによると思われる消化管潰瘍が 4 例に，带 状包疹が 3 例にみとめられた．そのほかにも心筋梗塞 疑いや脳梗塞疑いなどもみられた。これらは生命の予 後も左右する重大な合併症となる可能性があるため, 術前の十分な全身状態の把握が必要である. 特に, 非 ステロイド系消炎鎮痛剂を持続的に服用している RA 患者には，1990 年のリウマチ財団の報告 ${ }^{6)}$ で, 胃潰 瘍 $23.3 \%$, 十二指腸潰瘍 $4.5 \%$ の有病率があり, 胃 炎などの全病変を含めれば実に $61.8 \%$ がなんらかの 消化管病変を既に有しているのである，手術のストレ スにより,これらの病変が悪化する可能性が考えられ， 潰瘍治療薬（H2 ブロッカー）等の予防投与も必要で ある. また長期ステロイド投与患者には, 副腎予備能 の低下が危惧され， withdrawal syndrome の予防とし て，ステロイドカバーを㧍こなうことが必要となる. 3. 感染

RA では抵抗力の減弱により術後感染を起こしやす い状態にあると考えられ，感染予防を十分に行なう必 要がある. 当然であるが, 術中の清潔操作を厳重に行 ない，十分な洗浄と抗生物質の投与が不可欠である.

また遅発性感染にも十分な注意が必要である.
Bengtson 等 ${ }^{1)}$ は，感染を起こした 51 滕のうち，抗生 物質投与のみで治癒したものは 2 例, 軟部組織の処理 で治療したものが 3 例であり，一旦感染を起こせば人 工関節をそのまま温存する治療は困難であることを述 べている.また Schoifet 等 ${ }^{8)}$ は人工関節を温存して 治療した症例 31 例のうち 7 例 (23％） しか治癒しな かったとし，その原因を治療開始の遅れと起炎菌の違 いとしている. 我々は, 仮に遅発性感染が扔こっても 早期発見, 早期治療を行なえば治瘾し得ると考えてい る. 我々の症例でも， 2 例 3 膝に感染が起こったが, 持続灌流と抗生物質の投与で人工関節を温存したまま 感染の鎮静化に成功し, 現在まで再発はない.なお, このうち 1 膝は，TKR に針治療を行なっており,こ れが感染の原因と考えられる。このようなことがない ように十分な患者教育が必要である.

\section{TKR の局所的合併症}

ここに示した合併症の原因としては, 手術手技上の 問題, 軟部組織の脆弱性, 術後持続吸引不全などが考 えられた。

対策として術中操作を愛護的に行なうこと, 止血を 確実に行なうことが考えられた。また術後の膝関節の 腫脹軽減や皮下出血斑の軽減のために持続吸引器の改 良も望まれる。

\section{THR の局所的合併症}

THR の脱臼は，文献的には $1 \%$ - $11 \%$ 程度で 2) 3) 4) 7) ある. 今回の調査では, $10 \%$ に脱臼がみられ, 比較的頻度が高かった。

脱臼の原因は, もちろん術後早期に脱臼肢位動作を 行なった事であるが, RA のほとんどの症例にみられ る軟部組織の脆弱性, 筋力の低下やアンバランスにも 原因があると考えられた，各 component の設置角度 には，脱臼の原因は見いだせなかった．また，7例全 例が術後 1 力月以内に初回脱臼を抢こしていたが, 脱 臼後 3 週間の外転位での率引により 5 例は再脱臼を起 こさずに経過している.他の 2 例の内 1 例は, 術後 3 力 月目にも脱臼をおこした，同じ 3 週間の牽引により以 後は脱臼していない。もう 1 例は手術当日に意識障害 を㧍こし, 術後安静が守れず, 頻回の脱臼となった. 術後 4 力月目に観血的整復術を书こない，その後も 1 力月目に脱臼をおこしたがそれ以後の脱臼はない. 術後数力月間は, 術後管理及び患者指導を徹底するこ とが必要と思われた。また裖創は頻回の体位変換で防 ぎ得ると思われた。 


\section{ま と め}

1. 当科に扮けるRAに対する TKR 172 関節と THR 70 関節の術後合併症について検討した.

2. TKRの $30 \%$ と THRの $67 \%$ に輸血を必要とし, 特に術前に筫血のある症例では輸血の頻度が高かっ た.

3，消化管潰瘍の予防，感染予防など RA に特有な 全身状態に対する考慮が必要である。

4. THRの脱臼が 7 例にみられたが, 全例術後 1 力 月以内の初回脱臼であった．軟部組織の脆弱性と筋力 低下に原因があると考えられ，術後数力月間は十分な 術後管理が必要と思われた。

\section{参 考 文 献}

1) Bengtson, S., Knutson, K., and Lindgren, L. : Treatment of Infected Knee Arthroplasty. Clin. Orthop. 245 : 173-178, 1989.

2) Coventry, M. B. : Late Dislocations in Patients with Charnley Total Hip Arthroplasty. J. Bone and Joint Surg., 67-A (6) : 832-841, 1985.

3）松浦美喜雄, 寺内由行, 望月直哉, 宮崎憲太郎 : THR 後, 人工関節脱臼を起こした RA の 3 症例. 関節 の外科, $14: 110-115,1987$.

4) McCollum, D. E., and Gray, W. J. : Dislocation After Total Hip Arthroplasty. Clin. Orthop., 261 : 159-170, 1990.

5) Mylod, A. G., France, M. P., Muser, D. E., and Par sons, J. R. : Perioperative Blood Loss Associated with Total Knee Arthroplasty. J. Bone and Joint Surg., 72- A (7) : 1010-1012,1990.

6）日本リウマチ財団：非ステロイド抗炎症剤による消
化性潰瘍に関する疫学調査, 1990 .

7) Olerud, S., and Karlstrom, G. : Recurrent Dislocation after Total Hip Replacement. J. Bone and Joint Surg., 67-B (3) : 402-405, 1985.

8) Schoifet, S. D., and Morrey, B. F. : Treatment of Infection after Total Knee Arthroplasty by Debridement with Retention of the Components. J. Bone and Joint Surg., 72- A (9) : 1383-1390, 1990.

質 問国立別府病院 諫山 哲郎

(1) TKR における patella の脱臼とくにMGにおいて も少ないのは，手技上とくに注意すべき点であるので しょうか?

(2) $\mathrm{MG}$ の patella 脱臼は，手技上のみで防止可能な のですか?

(3) .キネマティックスタビライザータイプでの patella clunk syndromeの合併は経験されてませんか?

解 答国立福岡中央病院 和田 研 patellaの脱臼に関しては，ほとんどの症例に patella の lateral release を行なっており，術中に tracking がうまくいっているかを確認している．特に外反型、 怪骨外旋のある症例では, 外側の緊張が強く, patella の lateral release は絶対に必要と思われる. 一部，内 反型の症例では, lateral release の必要ない症例もあ る.

術後に patella の脱臼した 1 例は, 初期の症例で lateral release を行なっていなかった為の脱臼であり， lateral release の追加手術を行なって以後は脱臼して いない. 